\title{
MRI により診断された春髄髄内病変の経過
}

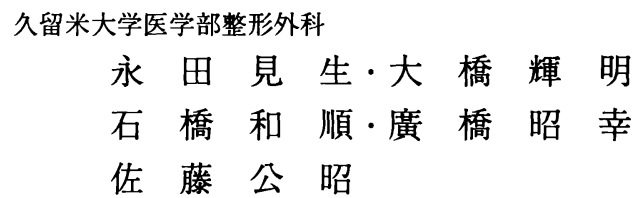

\section{Intramedullary Disorders Diagnosed by MRI : Clinical Course in 23 Cases}

\author{
by \\ Kensei Nagata, Teruaki Ohashi, Kazumasa Ishibashi, \\ Akiyuki Hirohashi and Kimiaki Sato \\ Department of Orthopaedic Surgery, \\ Kurume University School of Medicine, Kurume, Japan
}

\begin{abstract}
We report the clinical course of 23 cases with intramedullary disorders diagnosed by MRI. Spinal vascular disease was the most common, and occurred in 11 cases, intramedullary tumor occurred in 6, and multiple sclerosis, myelitis, spinal edema each in 2. The characteristic MRI findings of the intramedullary disorders were spinal cord swelling on T1 weighted image and changes in the intensity on the T2 weighted image. Surgical treatment was performed in 5 of the 11 with spinal vascular disease and in 6 with an intra-medullary tumor. One patient with AV malformation underwent embolization of the spinal artery. The other 11 received conservative treatment. The period of follow-up ranged from 6 months to 9 years after onset. Complete recovery from symptoms was achieved in only 2 patients, some recovery was achieved in 8 , no change in 10 , and deterioration occurred in 3 .

In conclusion, it has become easy to diagnose intramedullary disorders by utilizing MRI. However, an accurate qualitative diagnosis is difficult except for spinal vascular disease. Complete recovery from the symptoms of intramedullary disorders remains difficult to achieve by available treatments.
\end{abstract}

Key words : MRI (核磁気共鳴映像法), Intramedullary disorder (脊䯣内病変), Intramedullary tumor (脊髄髄内腫塲), hematomyelia (脊䯣出血), Multiple sclerosis（多発性硬化症）

\section{はじめに}

MRIの出現により従来診断が困難であった脊娟髄 内の病変が画像として捕らえられるようになり，治療 する機会が增えてきた，しかし，診断に苦慮するもの や，治療に難渋するものもあることから，その画像診 断の正確性が必要になってきた．今回教室で経験した

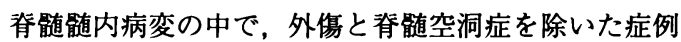
の概要を述へ，その臨床経過について報告する。

\section{対象および方法}

1986 年以降, 四肢麻疸や対麻㾝症状のために当科

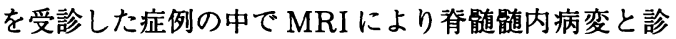
断され，経過が分かっているのは男 16 例，女 7 例の 計 23 例で, 年齢は 17 歳から 65 歳, 平均 45 歳である. これらの MRI 所見および臨床経過を調査した. 経過 観察期間は発症から最短 6 力月最長 9 年である. 
結果

MRI 所見により診断された症例は，血管腫瘍や動 静脈奇形を含む春髄血管障害が最も多く 11 例で，次 に脊䯣䯣内腫瘍が 6 例, 以下, 多発性硬化症, 脊䯣浮 腫，脊䯣炎と診断されたものが各々 2 例であった。発
症から MRI 診断までの期間は 1 週から 5 年，平均 9 カ月で, 脊䯣出血の一例が最短であった。

髄内病変の占拠高位はその上極で分類すると, 颈髄 が 12 例，胸髄が 7 例，脊髄円錐部が 4 例である.

診断に際しては, 一度の MRI で診断が可能であっ た症例が殆どであるが，複数回の検査やエンハンス
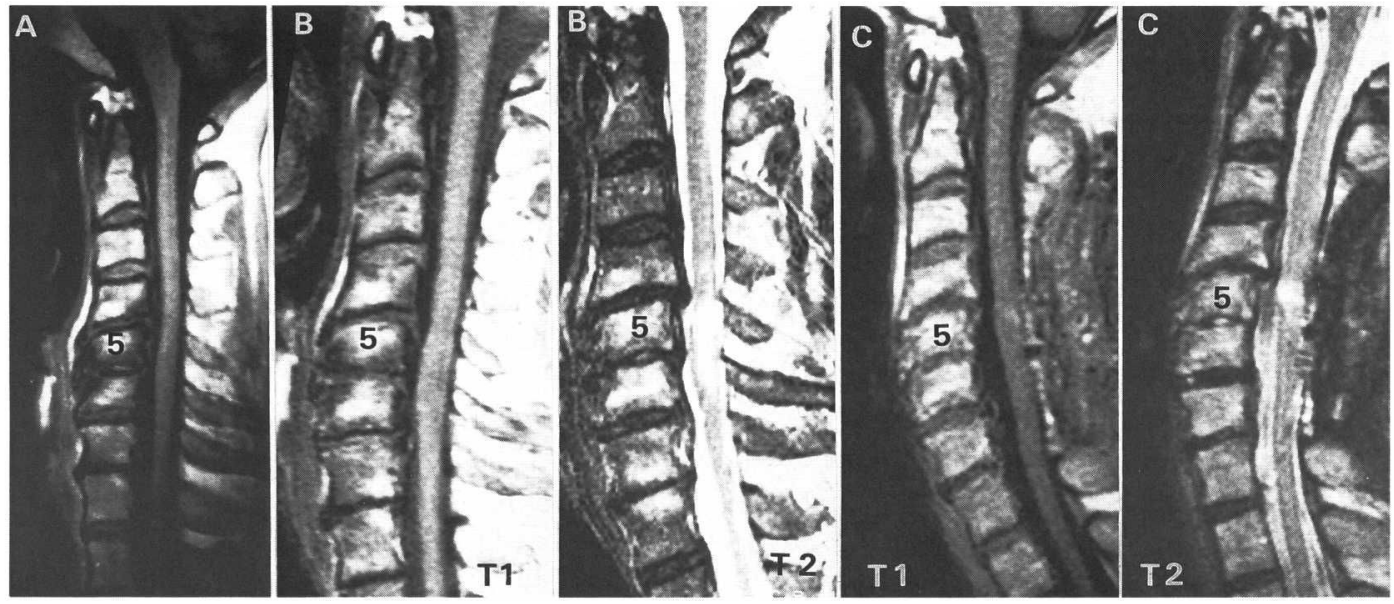

図 151 嵅 男性 顏椎症性脊䯣症で入院, JOA score 9 点, 症状のわりには（A）初 回 MRI で圧迫が軽度のため, (B) 再度 MRI 施行. C5-6 部に T1 強調像で脊䯣腫 大, T2 強調像で高信号域を認めた。摘出病理所見は fibrillay astrocytoma（細線 維性星細胞腫）であり，症状は若干改善した（C) 術後4 カ月の MRI.
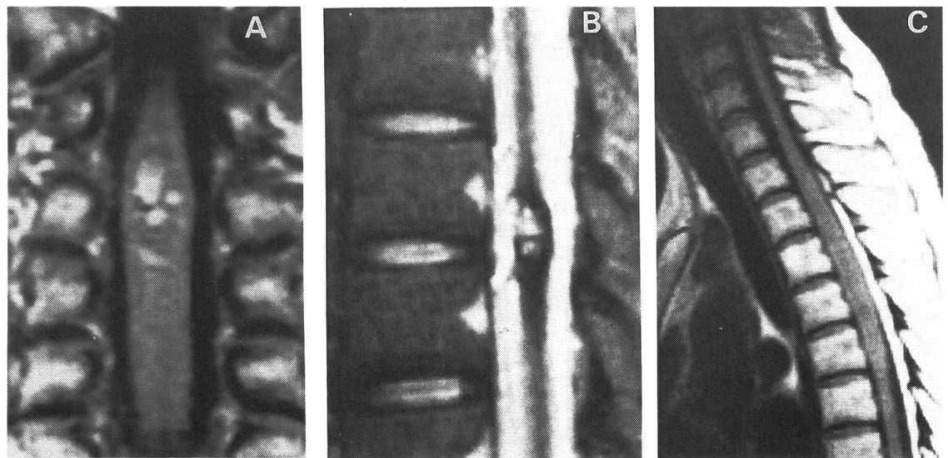

図 2 喵道内病変の MRI 所見

A：38藏 男性 C2-3 部の脊咀内出血, T1 强調像で鹃道内に高信号 領域を認める, 四肢麻㾝, 呼吸困難のため, 緊急手術後に重度の麻 瘦は改善したが㽷性不全麻㾇が残存した。

$\mathrm{B}: 38$ 歳 女性 $\mathrm{T} 9-10$ 部の海綿状血管腫, 数年来の対不全麻瘦で 来院，摘出術で症状はやや改善した，T2 強調像で高信号域を認め, 周辺は低信号である。

$\mathrm{C}: 22$ 歳 女性 T3-7 の astrocytoma, T1 強調像で脊䯣の腫大と やや高信号を認める. 対麻掼で部分摘出後, 麻疩が上行し約 10 カ 月後に呼吸麻㿎を来し死亡した。 
MRI が必要であった症例もある（図 1).

治療は, 手術施行例は血管腫の 5 例と腫瘍の 6 例の 計 11 例で, 動静脈奇形には塞栓術を施行した．血管 腫の 3 例と血管障害の 2 例, 多発性硬化症, 脊䯣浮腫, 脊䯣炎の各 2 例の計 11 例には保存的治療を行った。 保存的治療は主としてステロイドの内服とプロスタグ ラヂン E1の点滴投与である.

治療結果は，現時点で完治しているのは血管障害疑 いの 1 例と上衣腫手術例の 1 例の計 2 例のみで, 改善 が 8 例, 不変 10 例, 悪化 3 例であり, 胸髄に原発し た astrocytoma の 1 例は腫瘍が上行して死亡した。

脊髄出血, 血管腫, astrocytomaの症例を提示す る(図 2)。

\section{考察}

MRI で捕らえられる脊髄䯣内病変の中では，泰䯣 空洞症が $\mathrm{T} 1$ 強調像で低信号, $\mathrm{T} 2$ 強調像で高信号を 呈する領域が脊髄内に見られ診断が最も用意であり， また外傷性の病変も診断されやすい，今回はこれら以 外の春髄髄内病変の画像所見を調査検討した。泰䯣䯣 内病変の MRI 所見は, 一般的には脊䯣形態の変化と 髄内の輝度変化であり，脊髄形態の変化は脊髄の局所 的腫大として, 䯣内の輝度変化は低信号や高信号とし て捕らえられる。ささらに, 脊髄梗塞, 多発性硬化症, 腫瘍などでは血液－脊䯣・脳関門の破綻により $\mathrm{Gd}-$ DTPA でエンハンスされることより病態が明らかと なる病変もある.

脊䯣血管障害は今回の調査で最も多く, 泰髄出血, 脊髄梗塞, 血管奇形, 海面状血管腫の診断が可能であっ た。出血による髄内の輝度変化は, 発症からの期間に より信号強度が変化するので注意を要する，すなわち hemoglobin ( $\mathrm{Hb}$ ) の酸化還元, 赤血球崩壊 (溶血), 食細胞への取り込みの経過をとり, Hb から oxy-Hb, deoxy $\mathrm{Hb}$, met $\mathrm{Hb}$, hemosiderin へ変化する. この過程により信号強度が異なる（表 1 ）。脊䯣梗塞 は前脊髄動脈の血流支配領域である脊髄前方部分 $2 / 3$ に認められることが多く，頭尾側方向に鉛筆状に進展 する事が特徴的であり, T1 強調像で低ないし高信号, $\mathrm{T} 2$ 強調像で高信号を呈し, 経時的な浮腫の消退とと もに病変は縮小していく，海綿状血管腫の MRI 所見 は T1，T2 強調像ともに等なしい高信号の（nidus） の周囲に T2 強調像での低信号を認める ${ }^{3 / 5) 7-9)}$.
表 1 脊髄内血腫の MRI 所見

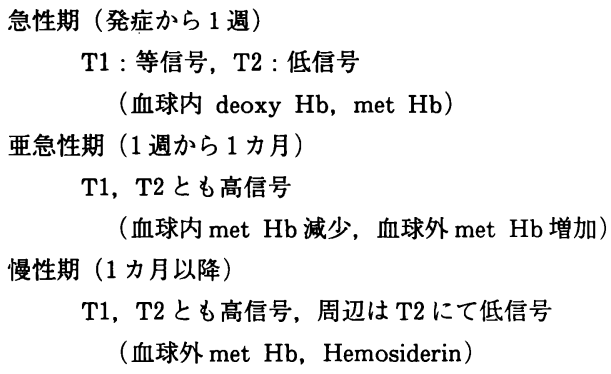

䯣内腫瘍は脳腫瘍の 50 分の 1 から 100 分の 1 の頻 度と言われ稀な疾患であり, glioma は $\mathrm{T} 1$ 強調像で 低あるいは等信号, T2 強調像で高信号を呈する，原 発性 glioma が $22 \%$, 上衣腫が $63 \%$ とされ，脊髄円

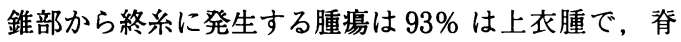
䯣上衣腫の $57 \%$ は終系に存在するとされ，脊䯣上衣 腫はその形態や好発部位により比較的診断がつけ易く， また lipoma は䯣内腫瘍の中で稀ではあるが $\mathrm{T} 1$, T2 強調像とも高信号を呈する特徴的な所見より最も診断 が容易である1).

多発性硬化症の MRI 所見は, ウィルスによる感染 性脊䯑道炎や膠原病による横断性脊能炎との鑑別が困難 であると言われている．本症は病期により異なり，急 性増悪期には $\mathrm{T} 1$ 強調像で脊䯣腫脹を呈し信号変化は 少なく、T2 強調像では脊髄腫脹と高信号がみられる. この脊咀腫脹と高信号は，主として脱㕼機転により生 じた炎症，浮腫を表すと想定され，その T2 高信号の 検出率は䅡髄で 70\%, 胸腰髄で50\% と言われている. 寛解期には脊䯑道腫脹は消失し, T2 高信号は次第に不 明瞭となるとされている6).

脊髄浮腫の診断は 2 例であるが，そのうちの 1 例は Harada $~^{2)}$ や伊藤ら ${ }^{4)}$ が報告した症例の MRI 所見 に極めて類似し，伊藤らは脊髄浮腫と推測していたの で，我々も脊髄浮腫と分類したが，圧迫性脊鹃症とし ては術前の圧迫程度が軽微であり，脊䯣血管障害に入 れた方が適当であるかもしれない（図 3).

以上, 教室で経験し経過が判明している脊䯣䯣内病 変について述べたが，本病変は稀であり，一施設で取 り扱う症例には数に限りがあるので症例を持ち寄って 知識を深める必要がある。 

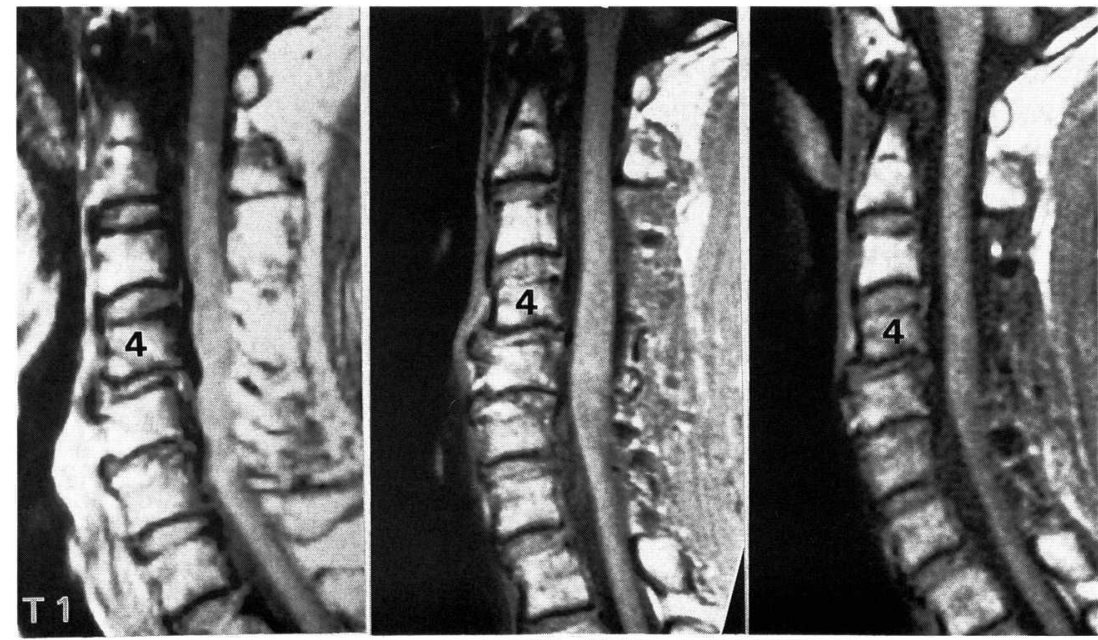

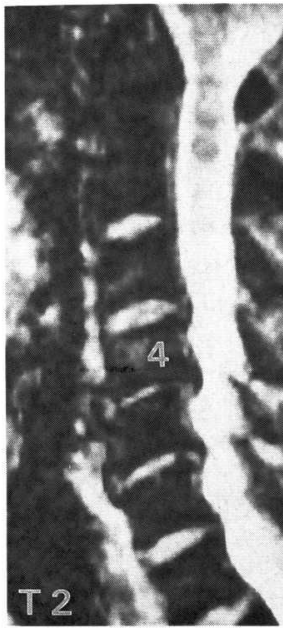

before op.

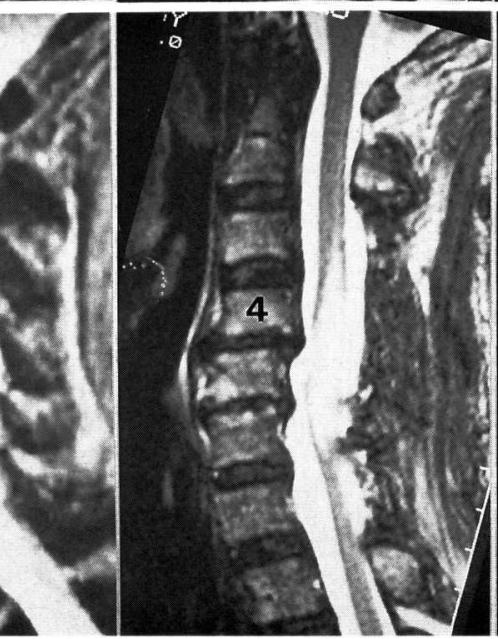

7 wks. after op.

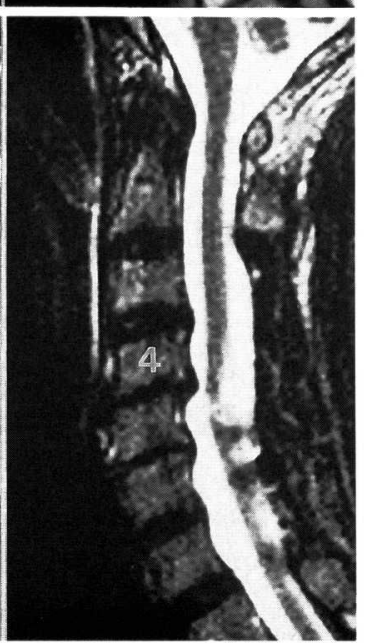

9 mos. after op.

図 365 藏 男性 頚椎症性脊䯣症に対して春柱管拡大術を施行, 術前 MRI では T1 強調像で C4 から C6 にかけて高信号を呈し, 術後 7 週の $\mathrm{T} 1$ 強調像で脊髄の腫大, $\mathrm{T} 2$ 強調像で高信号域を広範囲に認 めたが, 術後 9 カ月では $\mathrm{T} 1$ 強調像で脊髄腫大は改善, $\mathrm{T} 2$ 強調像で の高信号領域も縮小した，術前後で症状は不変であった。

上段： $\mathrm{T} 1$ 強調像の経過, 左から術前, 術後 7 週, 術後 9 力月

下段：T2 強調像の経過, 左から術前, 術後 7 週, 術後 9 力月

ま と め

MRI で診断された脊髄䯣内病変23例について報告 した.

春髄血管障害, 腫瘍が多く, 脊髄の腫大, 信号変化 とその形態で脊䯣髄内病変の診断ができるが, 正確な 質的診断は困難な事も多い.
MRI 画像と臨床症状が合致しない場合は，ほかの 検查に加え，複数回の MRI が有用な症例がある.

脊髄䯣内病変のなかでも，保存療法が有効な場合が ある。

\section{参 考 文 献}

1) Hackney, D. B.: Magnetic Resonance Imaging of 
the Spine. Neoplasms and related disorders. Topics in Magnetic Resonance Imaging, 4 : 37-61, 1992.

2) Harada, A. and Mimatsu, K.: Postoperative Changes in the spinal Cord in Cervical Myelopathy Demonstrated by Magnetic Resonance Imaging. Spine, $17: 1275-1280,1992$.

3）井須豊彦ら：脊髄葡内海綿状血管腫の MRI 診断と外 科的治療. 臨整外, $28: 1343-1348,1993$.

4) 伊藤友一ら：術後 MRI で脊髄腫大傾向を示した䅡䯣 症の 2 例. 臨整外, $30: 755-759,1995$.

5）木下知明ら：短期間に再出血を繰り返した脊㖪内出血
の 1 例. 関東整災誌, $23: 43-47,1992$.

6）小島重幸：脊髄脱髄疾患における MRI. MB Orthop. 7 (11 增刊) : 103-111, 1994.

7）宮坂和男：春䯣血管病変における MRI. MB Orthop. 7(11 増刊) : 112-120, 1994.

8) Ogilvy, C.S., Louis, D. N., Ojemann, R. G.: Intramedullary cavernous angiomas of the spinal cord. Neurosurgery, $31: 219-230,1992$.

9) Zenter, J., et al.: Intramedullary cavernous angiomas. Surg. Neurol., $31: 64-68,1989$. 